\section{Training for Africans in Africa}

SIR - You suggest (Nature 371, 269; 1994) that the Republic of South Africa should do more to train young Africans in the techniques of palaeoanthropology.

This department at the University of Witwatersrand has, under Raymond Dart's leadership (1923-59) and then under Phillip Tobias's (1959-90), been recognized as an international centre of expertise in palaeoanthropology.

It was in this department that Dart removed the 'Taung child' (Australopithecus africanus) from its breccia, and Tobias and his colleagues have made remarkable early hominid discoveries at Sterkfontein, Makapansgat and Gladysvale. During this period, the teaching of human evolution was prohibited within the South African public educational curricula, but the tradition of palaeoanthropological research within a South African context continued, and is continuing unabated, as the 'new South Africa' takes shape under President Nelson Mandela's leadership. Undergraduate science courses here have, for 75 years, taught palaeoanthropology to South African students and these have recently been revamped to encourage the development of African postgraduate research students.

The department's Palaeoanthropology Research Unit (PARU) houses one of the world's largest collections of early hominid fossil remains, and these are continuously being visited and studied by the world's leading palaeoanthropologists.

A new, South African based non-profit organization, the Palaeo-Anthropological Scientific Trust (PAST), has recently been established to promote palaeoanthropological research in southern Africa having as its expressed mission the education of Africans about their prehistoric past.

The trust is unique in being based in Africa and in being supported financially primarily by South Africans. The education mission will be achieved through educational programmes, scholarships and the promotion of opportunities for African students, and students from throughout the world, to learn the skills required to become palaeoanthropologists of the highest international quality.

In 1995 the first 'palaeoanthropological summer school', designed to give training in the scientific methods required for palaeoanthropological research in southern Africa, will be initiated at the University of Witwatersrand with the financial support of PAST.

Budgeting has been so constructed that suitably qualified African applicants will be able to attend virtually free of charge. In this way the "hope" for free-standing expertise in the sub-Saharan centres is being realized and, perhaps most imporple of Africa.

Noël Cameron

Lee R. Berger

Jeffrey K. McKee University of the Witwatersrand,

7 York Road, Parktown,

Johannesburg 2193, South Africa they already have a child. evidence of this. tantly, this initiative comes from the peo-

Department of Anatomy \& Human Biology,

\section{Population control Telescope site at not the answer Mount Graham}

SIR - Two recent leading articles in Nature (370, 583-584 \& 371, 185; 1994) regarding the Third International Conference on Population and Development deserve much thought and comment. The very idea that political institutions such as the United Nations have either the right or the ability to direct demographic transitions related to population control is not only pretentious but also unsupported by any historical precedent. Far from providing increased levels of freedom for all, or specifically providing increased "empowerment for women", any sort of population control statement can serve only to imprison people (in particular women) in a place where freedom is all but a distant memory. Population policies such as those proposed at Cairo serve to legitimize practices such as those in China where women are not only allowed to have abortions, but are required to do so if

The first leading article suggests that it is the presence of "uncivil inequalities between rich and poor that mar too many people's lives" that is really the issue at stake, not hysterical fears that the planet cannot support in excess of 7 billion inhabitants. Clearly, the writer has ignored the more important issue of the struggle for political power as a major contributor to "marred lives". Some of the most inegalitarian and underdeveloped nations, those at which the conference's statements are primarily aimed, have no need of population control policies at all; the wholesale slaughter of more than 100,000 in Rwanda and the use of food as a political weapon in Somalia are ample

The basic assumptions underlying the United Nations' desire to orchestrate improved living conditions and world harmony through population control are noble, and even plausible at first glance. Upon closer examination, it becomes clear that population control is not the answer because it does not address the underlying root of unrest and inequality in the world. For all of recorded history, man has been cruel to his fellow man in order to serve his own desires; this has been a constant regardless of world population of demographics. To think that man can by himself solve these problems with statements of policy and forced "moral" (that is, the new morality of liberalism) behaviour is the utmost in arrogance.

Thomas A. Bicsak

407 Bigley Road,

Neshanic Station,

New Jersey 08853, USA

SIR - The Commentary (Nature 372, 215-216; 1994) by University of Arizona astronomers ignores the views of Native Americans about our Mother Earth. To us Apaches, Dzil Nchaa Si An (Mount Graham) is a most sacred mountain. It is the home of the $G a^{\prime}$ an or mountain spirits. The Ga'an give the Apache people guidance, direction, knowledge and healing. Since time immemorial we have gathered special plants and herbs there. Many of our dead are buried there. Our elders and Medicinepeople have signed petitions opposing this desecration. Our tribal council informed the university of our opposition in December 1989. Our council reaffirmed its opposition on 10 July 1990. The university, the Vatican Observatory and the Max Planck Institute ignored our pleas and protests. They levelled the trees at the summit telescope sites on 2 October 1990. Subsequent council objections in June 1991, December 1992, May 1993 and as recently as October 1994 have also been ignored.

Finally, when we sued them, the court said we did not give them enough advance notice! Astonishingly, the astronomers argued in court that their project was excempt from all laws protecting Native American cultural and religious values plus all environmental laws as a result of a rider they had spent millions of dollars lobbying through Congress. The court refused to consider the long-standing scholarly proof in the university's own library, or the affidavits of our Medicinepeople and elders about the mountain's sacredness.

As studies by White astronomers show superior astronomy sites both in the continental United States, Hawaii and Chile, it is difficult to understand why "enlightened' educated institutions are still, today, warring against our beliefs.

Ola Cassadore Davis

Chairperson

Apache Survival Coalition,

Box 1237 ,

San Carlos,

Arizona 85550, USA 